Utah State University

DigitalCommons@USU

Reports

Utah Water Research Laboratory

2013

\title{
The Sky is Falling: Chemical Characterization and Corrosion Evaluation of Deposition Produced During the Static Testing of Solid Rocket Motors
}

William J. Doucette

La S. McNeill

Utah Water Research Laboratory; Utah State University

Scout Mendenhall

Molzen-Corbin

Paul V. Hancock

ATK Launch Systems

Jason E. Wells

ATK Launch Systems

Kevin J. Thackeray

ATK Launch Systems

Follow this and additional works at: https://digitalcommons.usu.edu/water_rep

See next page for additional authors

Recommended Citation

Doucette, William J.; McNeill, La S.; Mendenhall, Scout; Hancock, Paul V.; Wells, Jason E.; Thackeray, Kevin J.; and Gosen, David P., "The Sky is Falling: Chemical Characterization and Corrosion Evaluation of Deposition Produced During the Static Testing of Solid Rocket Motors" (2013). Reports. Paper 677.

https://digitalcommons.usu.edu/water_rep/677

This Article is brought to you for free and open access by the Utah Water Research Laboratory at

DigitalCommons@USU. It has been accepted for inclusion in Reports by an authorized administrator of DigitalCommons@USU. For more information, please contact digitalcommons@usu.edu.

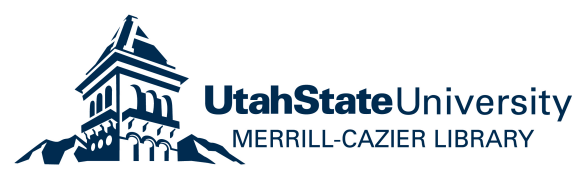


Authors

William J. Doucette, La S. McNeill, Scout Mendenhall, Paul V. Hancock, Jason E. Wells, Kevin J. Thackeray, and David P. Gosen 


\title{
The sky is falling: chemical characterization and corrosion evaluation of deposition produced during the static testing of solid rocket motors
}

\author{
William J. Doucette, ${ }^{a,{ }^{*}}$ Laurie S. McNeill, ${ }^{a}$ Scout Mendenhall, ${ }^{b}$ Paul V. Hancock, ${ }^{c}$ Jason \\ Wells, ${ }^{c}$ Kevin Thackeray, ${ }^{c}$ and David P. Gosen ${ }^{d}$ \\ $a^{*}$ Corresponding Author: Utah Water Research Laboratory, Utah State University, 8200 Old \\ Main Hill, Logan UT 84322, USA. Email: william.doucette@usu.edu; Fax: +1.435.797.3663; \\ Tel: +1.435 .797 .3178$ \\ bMolzen-Corbin, 2701 Miles Road SE, Albuquerque, NM 87106, USA. \\ cATK Launch Systems, 9160 North Highway 83, Corinne, UT 84307, USA. \\ dUnivar, 17425 NE Union Hill Rd, Redmond WA 98052
}

\begin{abstract}
Static tests of horizontally restrained rocket motors at the ATK facility in Promontory UT, USA result in the deposition of entrained soil and fuel combustion products, referred to as Test Fire Soil (TFS), over areas as large as 30-50 square miles $\left(80-130 \mathrm{~km}^{2}\right)$ and at distances up to $10-12$ miles $(16-20 \mathrm{~km})$ from the test site. Chloride is the main combustion product generated from the ammonium perchlorate-aluminum based composite propellant. Deposition sampling/characterization and a 6-month field corrosivity study using mild steel coupons were conducted in conjunction with the February $25^{\text {th }} 2010$ FSM-17 static test. TFS deposition rates at the three study sites ranged from 1 to $5 \mathrm{~g} / \mathrm{min} / \mathrm{m}^{2}$. TFS contained significantly more chloride than the surface soil collected from the test site. TFS collected during two subsequent tests had similarly elevated chloride, suggesting that the results obtained in this study are applicable to other tests assuming the rocket fuel composition remains similar. The field-deployed coupons exposed to the TFS had higher corrosion rates (3.6 - $5.0 \mathrm{mpy})$ than paired non-exposed coupons (1.6 - $1.8 \mathrm{mpy})$. Corrosion rates for all coupons decreased over time, but coupons exposed to TFS always had a higher rate than the non-exposed. Differences in corrosion rates between the three study sites were also observed, with sites receiving more TFS deposition having higher corrosion rates.
\end{abstract}

Keywords: rocket, deposition, corrosion, chloride, aluminum 


\section{Introduction}

As part of a multi-year program designed to evaluate and improve the performance and safety of reusable solid rocket motors (RSRMs), static ground tests are conducted at the Alliant Techsystems (ATK) Promontory, Utah facility. During static tests, the heavily instrumented RSRMs, containing an ammonium perchlorate-aluminum based composite propellant, are horizontally restrained and ignited while data on performance are collected. During a typical 2minute test, a high-temperature cloud of combustion products and an estimated 1.5 million $\mathrm{kg}$ of entrained soil are generated. This combustion cloud typically reaches heights of 10,000-15,000 feet above ground surface.

As the cloud cools, the deposition material, referred to as Test Fire Soil (TFS), drops on the surrounding area (usually at a 10-20 degree angle that extends out to 10-12 miles) that includes rangeland, farmland, low-density residential housing and several wildlife management areas. Due to its exposure to elevated temperatures (combustion gas temperatures approach $6,000^{\circ} \mathrm{F}$ ) and combustion products (largely aluminum oxide and hydrogen chloride [Dreschel and Hall, 1990]), the composition of the Test Fire Soil (TFS) is expected to be different from the native soil.

Monitoring conducted during several past Space Shuttle launches and vertically restrained static rocket motor tests having similar fuel composition provides some pertinent information on the potential constituents and impact of the deposition material generated during the static tests. The typical RSRM used in the Space Shuttle program contained over 500,000 kg of a composite propellant comprised of an ammonium perchlorate oxidizer (70\%), an aluminum powder fuel (16\%), a polybutadiene-acrylic acid-acrylonitrile terpolymer (PBAN) binder (12\%), an epoxy curing agent ( $2 \%$ ), and a catalyst of iron oxide powder $(0.1 \%)$ (Dreschel and Hall, 1990). The main exhaust products were aluminum oxide $\mathrm{Al}_{2} \mathrm{O}_{3}(30 \%)$, carbon monoxide $\mathrm{CO}$ (23\%), hydrogen chloride $\mathrm{HCl}(22 \%)$, water (10\%), and nitrogen (8\%) (Dreschel and Hall, 1990). Hydrochloric acid is formed when the $\mathrm{HCl}$ gas dissolves in the water produced during combustion and the existing atmospheric water vapor (humidity). From bulk deposition collectors used during three shuttle launches at Kennedy Space Center in Florida USA, Dreschel and $\mathrm{Hall}$ (1990) estimated $\mathrm{HCl}$ and $\mathrm{Al}_{2} \mathrm{O}_{3}$ deposition to range from $0-127 \mathrm{~g} / \mathrm{m}^{2}$ and $0-246 \mathrm{~g} / \mathrm{m}^{2}$, respectively. The deposition was highly influenced by wind speed and direction and led to shortterm decreases in soil and water $\mathrm{pH}$ surrounding the Kennedy Space Center after shuttle 
launches. At a NASA test facility in Mississippi, Nowak and Friend (2006) observed that soil $\mathrm{pH}$ was decreased by vertically restrained static rocket tests, but only temporarily because alkalinity in the soil neutralized the acid.

In contrast to the Space Shuttle launches and vertically restrained static tests, the plumes generated from the horizontally restrained static tests in Northern Utah contain large quantities of soil. For very large rocket motors, horizontal mounting is easier and provides better access to the motor. Safety considerations and space limitations required placing the large motor static test sites close to a small mountain range that makes up the western boundary of the facility. The rising grade behind the test facility creates a point where the high thrust exhaust entrains large amounts of soil and rock.

Using aircraft to make real time measurements, Cofer et al. (1993) found that the number of large diameter particles ( $>5 \mathrm{um}$ ) in the Utah site's static test exhaust cloud was greater than that of a shuttle launch and most of the large material was composed of soil debris. They also found that although the peak atmospheric $\mathrm{HCl}$ concentrations during a static test in Utah were slightly greater than that observed during a shuttle launch in Florida ( 50 ppm $_{\mathrm{v}} \mathrm{Vs} .35 \mathrm{ppm}_{\mathrm{v}}$ ), the $\mathrm{HCl}$ concentrations decreased from the peak much more rapidly at the Utah site. We speculate that the relatively alkaline soil ( $\mathrm{pH} \mathrm{8,30 \%} \mathrm{carbonate} \mathrm{content)} \mathrm{entrained} \mathrm{in} \mathrm{the} \mathrm{combustion} \mathrm{cloud}$ neutralized some of the $\mathrm{HCl}$.

Questions regarding the composition and potential corrosivity of the TFS generated during static rocket testing prompted this investigation. Deposition material (TFS) was collected during the February 2010 FSM-17 static test and analyzed for chloride and other major anions and metals. This material was also compared to TFS collected during several other static tests in order to evaluate compositional variability. To assess the potential corrosivity of the TFS under environmental conditions and compare it to other locations, fifteen, pre-weighed, standard mild carbon steel specimen coupons were mounted on tripod stands, 15 minutes before the February 2010 static test at the three sites within the projected deposition plume (exposed). After the deposition was visually observed to have stopped, a second panel of 15 coupons was mounted next to the exposed panel (non-exposed). Triplicate coupons were collected from each set at five times over a six-month exposure period and were cleaned to remove the corrosion byproducts. Corrosion rates, determined from weight loss measurements, were compared to those obtained from non-exposed samples and to literature values. 


\section{Experimental}

The FSM-17 static rocket motor test started at 11:50 am MST on February 25, 2010. Sky conditions were mostly cloudy with a light morning fog dissipating by the time of the test. Winds above 10,000 feet mean sea level (MSL) were out of the northwest at $10 \mathrm{~m} / \mathrm{s}$. Temperatures at 10,000 and 20,000 feet MSL were -10 and $-20^{\circ} \mathrm{C}$, respectively. Weather conditions were monitored by ATK meteorologists and used to make pre-test plume path predictions and select three sites for the collection of deposition material and the initiation of a six-month corrosion monitoring experiment (Figure 1). Sites were located at approximately $41^{\circ} \mathrm{N}$ $112^{\circ} \mathrm{W}$ with elevation ranging from 1327 to $1448 \mathrm{~m}$. All three sites did receive TFS deposition, although snow cover and atmospheric conditions likely limited soil entrainment based on visual and radar comparisons with previous static tests.

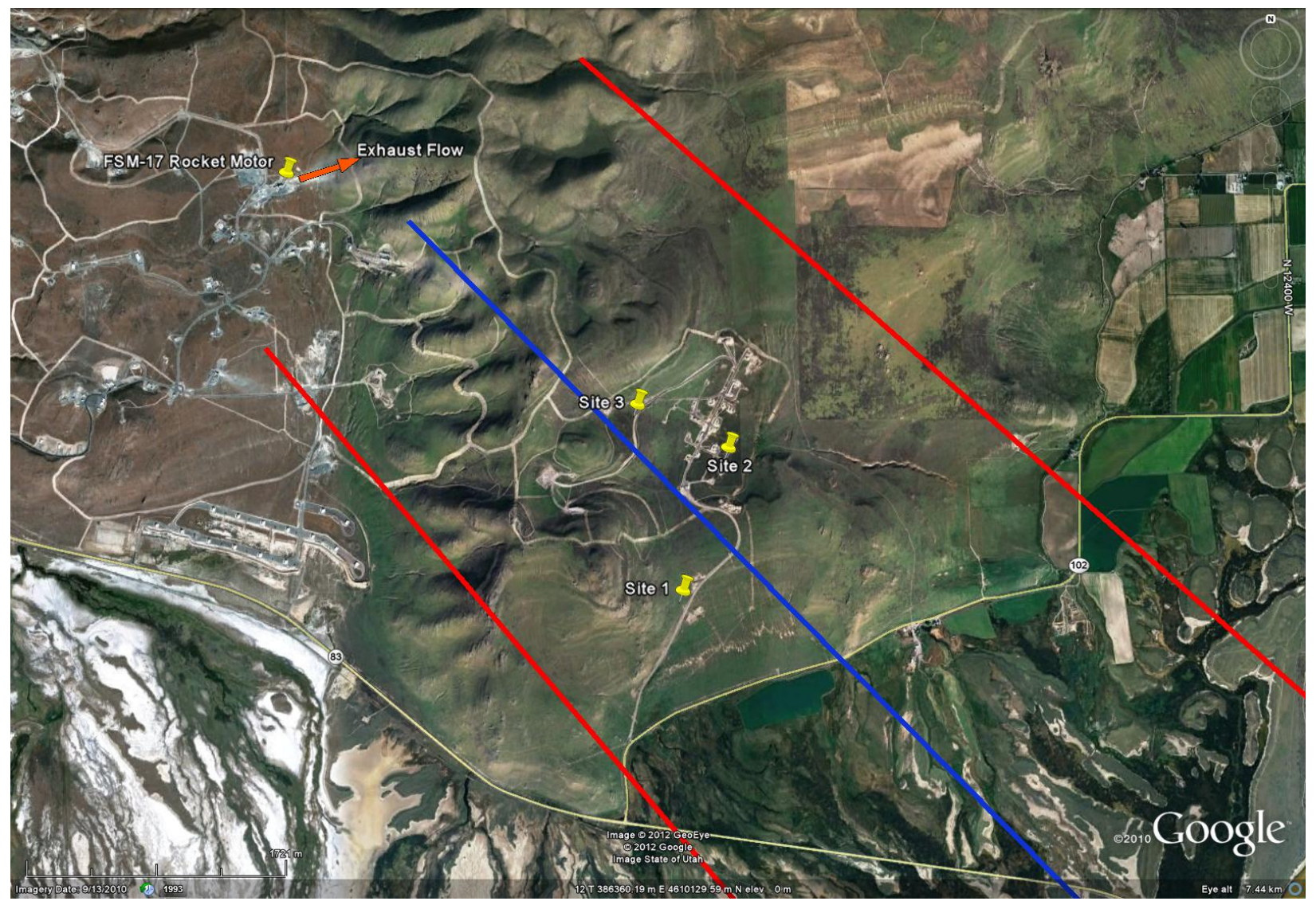

Fig. 1. Sampling locations for the FSM-17 static rocket motor test. Red lines indicate the approximate plume deposition boundary and blue line represents the plume centerline, determined from Next Generation Radar (NEXRAD) plume signatures. 


\subsection{Deposition material (TFS) collection}

Polyethylene tarps $\left(3 \mathrm{~m}^{2}\right)$, placed on the ground at each of the three locations just before the start of the static motor test, were used to collect TFS for the post-test characterization of inorganic materials (major anions and metals). Universal $\mathrm{pH}$ paper test strips placed on the tarps were used to provide a rough estimate of $\mathrm{pH}$ since the amount of wet deposition collected was insufficient for the use of a standard $\mathrm{pH}$ probe and meter. After the deposition stopped, the collected material was transferred from the tarp into a labeled HDPE bucket using a nylon scraper. The buckets were sealed and transported to the Utah Water Research Laboratory (UWRL, Logan UT, USA) where the material was allowed to air dry for two days. After drying, the material was weighed and transferred to HDPE plastic containers pending characterization. Large stainless steel bowls (12 inch diameter) were used to collect TFS for organic material characterization but insufficient material prevented analysis. Soil cores $(10 \mathrm{~cm} \times 2.5 \mathrm{~cm}$ diameter) were also collected at the test site using a hand driven ASM soil corer (American Fork, ID, USA) and divided into four $2.5 \mathrm{~cm}$ sections prior to analysis. However, since no trends in metals or major ion concentrations were observed with depth, results for the soil cores are presented as the average and standard deviation for all four sections.

\subsection{TFS and soil analysis}

For anion analysis, five-gram samples of air-dried TFS or soil were added to $5 \mathrm{~mL}$ of deionized water (DI) in $40 \mathrm{~mL}$ polyethylene centrifuge tubes. The tubes were agitated for 48 hours on a rotary tumbler operating at $40 \mathrm{rpm}$, then centrifuged at $5000 \mathrm{~g}$ for $15 \mathrm{~min}$ to separate the phases. An aliquot of supernatant, diluted if necessary to stay within the instrument calibration range, was analyzed using a Dionex DX500 Ion Chromatography system equipped with a $50 \mathrm{~mm}$ guard column, $250 \mathrm{~mm} \times 4.5 \mathrm{~mm}$ AS11-HC analytical column and a CD20 conductivity detector. The isocratic elution program utilized a $30 \mathrm{mM} \mathrm{NaOH}$ solution at a flow rate of $1.5 \mathrm{~mL} /$ minute.

A microwave digestion procedure was used to prepare soil and TFS for metals analysis. The digestion procedure followed USEPA Method 3050B (USEPA 1996). Approximately $0.5 \mathrm{~g}$ soil was placed in an APCU-40 75 mL TFM vessel (Milestone, Italy). Sides of the vessel were rinsed with $5 \mathrm{~mL}$ de-ionized water, to which $9 \mathrm{~mL}$ concentrated nitric acid (trace metal grade, Fisher Scientific) and $2 \mathrm{~mL}$ hydrogen peroxide $30 \%$ by weight (Certified ACS, Fisher Scientific) 
were added. These were capped in an APCU-TR40 Safety Shield (Milestone, Italy), and placed in an Ethos EZ Microwave Digestion System (Milestone, Italy). The samples experienced a 15 minute ramp time to reach $200^{\circ} \mathrm{C}$, after which they were held at constant temperature for 30 minutes, and then allowed a cool-down period of 20 minutes. Samples were diluted to $100 \mathrm{~mL}$ in a volumetric flask and filtered using Whatman No. 42 filters before analysis. Each batch of digestions included 3 blanks.

Metal analysis was performed using an Agilent 7500c Inductively Coupled Plasma-Mass Spectrometer (ICP-MS) following procedures outlined in USEPA Method 6020A (US EPA 2007). The instrument was calibrated using external standards prepared from a certified stock (High-Purity Standards, Charleston, SC). Internal standards were Sc, Ge, In, and Tb. Helium collision mode was used to remove interferences for the analysis of $\mathrm{V}, \mathrm{Cr}, \mathrm{Mn}, \mathrm{Fe}, \mathrm{Co}, \mathrm{Ni}, \mathrm{Cu}$, $\mathrm{Zn}$, and As. Hydrogen reaction mode was used for Se analysis. All other metals were analyzed without the reaction cell. Quality control samples included blanks, calibration verification samples, and duplicate matrix spikes.

\subsection{Corrosion monitoring}

Fifteen, pre-weighed, standard mild carbon steel specimen coupons (1018 mild carbon steel, $0.125 "$ x $0.875 "$ x 2.875", $5.683 \mathrm{in}^{2}=36.666 \mathrm{~cm}^{2}$, part number CO1113770201120, Metal Samples Co. Inc., Munford AL), fastened to plexiglass panels using plastic zip-ties or nylon bolts, were mounted on south-facing 45 degree angle tripod stands, 15 minutes before the static motor test at the three sites within the projected deposition plume (Figure 1). After the deposition was visually observed to have stopped, a second panel of 15 coupons was mounted next to the exposed panel (Figure 2). Each tripod was anchored by sand bags and equipped with a temperature/humidity datalogger (HOBO U23 Pro v2, Part Number U23-001, Onset Inc., Bourne MA). 


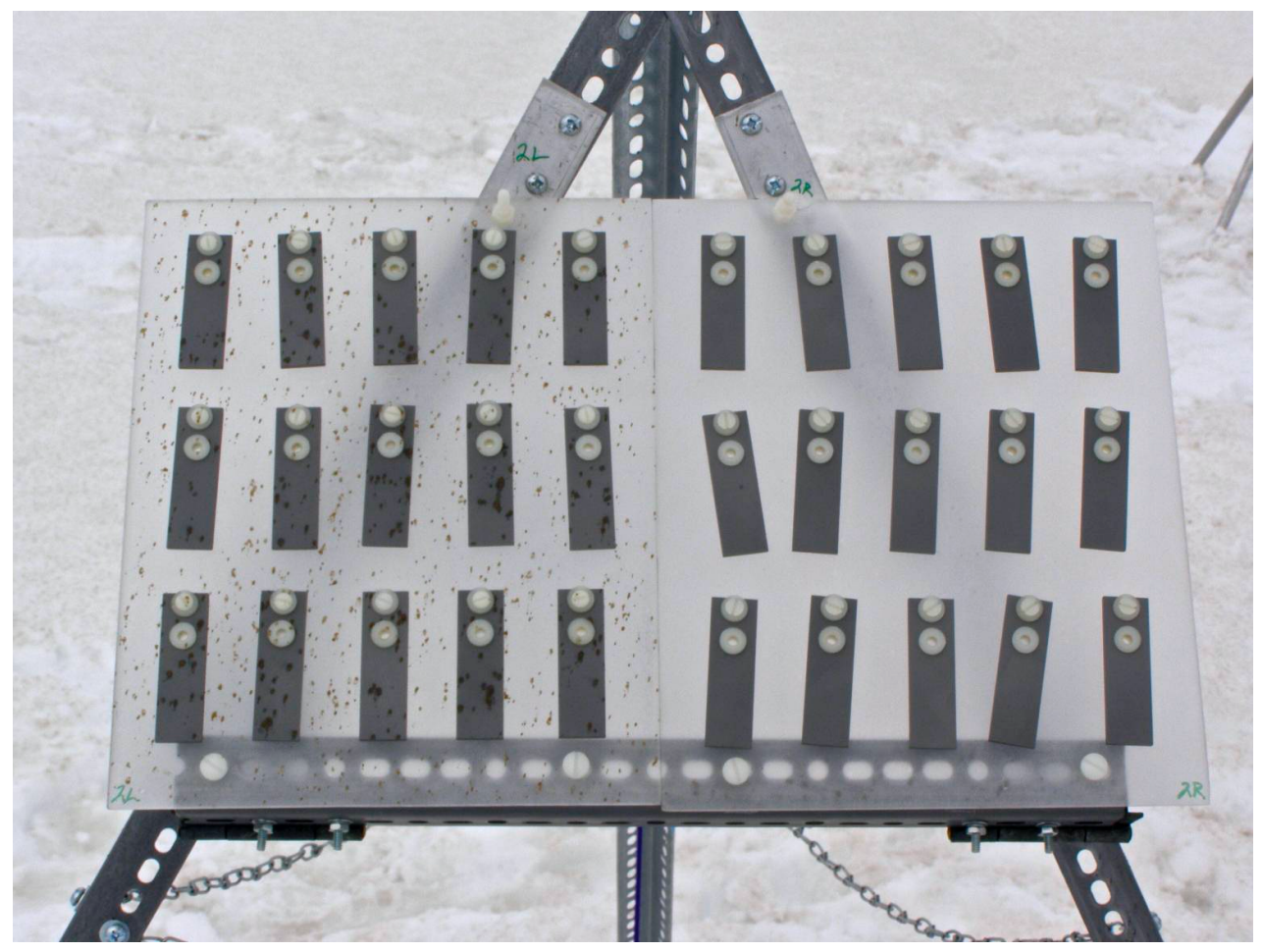

Fig. 2. Example photograph of exposed (left panel) and non-exposed (right panel) steel coupons taken at Site 2 on February 25, 2010. Photograph was taken shortly after the deposition stopped and the non-exposed coupons were placed into position.

During each of the five sampling events (March 4, April 2, June 17, July 20 and August 17, 2010), three coupons were removed from each panel and placed in paper sample envelopes. Coupons were selected for removal using the random number generating function "RANDBETWEEN" in Microsoft Excel. After collection, samples were placed in a desiccator for 48 hours, photographed, and then sent to Metal Samples Co Inc. (Munford AL) for weight loss analysis. The coupons were cleaned in a blasting cabinet using a fine glass abrasive at 40-50 psi for 2-3 minutes with the cleaning time dependent on the amount of corrosion observed on the samples. Coupons showing minimal corrosion were gently wiped with acetone instead of being subjected to the abrasive cleaning. After cleaning, the coupons were then re-weighed. Corrosion rates (mil/year, or mpy) were calculated for all coupons based on weight loss and time of exposure.

Sometime between Friday, February 26, 2010 and Monday, March 1, 2010 the corrosion test panel at Site 1 was knocked over by wind or grazing cattle. The Plexiglas metal coupon 
support separated from the tripod and was found face down on the ground. All coupons were still attached to the plate. The test panel was reassembled Monday, March 1, 2010 and was surrounded by a fence.

\subsection{Statistical analysis}

All statistical analyses were done using the statistical program R, version 2.12.1 (R Core Team, 2012). Metal and ion concentration data were evaluated using a standard ANOVA, while corrosion rate data were analyzed using a Repeated Measures ANOVA. As the rate data violated Mauchley's test for sphericity (homogeneity of variances) (Winer et al., 1991), the ANOVA Fstatistic was corrected by an epsilon-factor (Von Ende, 2001).

\section{Results and discussion}

\subsection{TFS deposition collection}

The static rocket motor test started at 11:50 AM, February 25, 2010, and deposition was first noted at 11:56 AM, 11:58 AM, and 12:02 PM at Sites 3, 2, and 1 respectively. The deposition period ranged from 4 to 8 minutes (Table 1). The total area of deposition was estimated to be $\sim 20$ square miles from Next Generation Radar (NEXRAD) plume signatures. The $\mathrm{pH}$ test trips located on the deposition collection tarp indicated that some of the liquid deposition at all sites had a $\mathrm{pH}<2$, although it was quickly neutralized as it reacted with solid deposition material. Subsequent tests showed that the $\mathrm{pH}$ of the TFS varied from 9 to 11 , depending on the age of the material. The elevated $\mathrm{pH}$ values were due to the high temperature conversion of calcite to calcium oxide that then reacted with water to form calcium hydroxide. 
Table 1

TFS Deposition Rates

$\begin{array}{lll}\text { Site } 1 & \text { Site } 2 & \text { Site } 3\end{array}$
Distance from motor $(\mathrm{km})$
3.6
3.1
2.5
Distance from estimated plume centerline (m)
500
375
150
Deposition duration (min)
8
4
6
Deposition rate $\left(\mathrm{g} / \mathrm{min} / \mathrm{m}^{2}\right)^{*}$
$1.1 \pm 0.0$
$3.8 \pm 0.1$
$5.2 \pm 0.2$

*Deposition rates are based on duplicate measurements

\subsection{Deposition characterization}

\subsubsection{Anions}

The results of the anion analysis are summarized in Table 2. Chloride was the dominant anion as expected, with concentrations ranging from 23000 to $34000 \mathrm{mg} / \mathrm{kg}$, and all TFS samples were three orders of magnitude greater than the test site background soil (collected just outside the static test impacted area). Sulfate concentrations in the TFS were also elevated relative to the surface soil, while nitrate was lower in the TFS. All of these trends were found to be statistically significant $(\mathrm{p}<0.05)$.

\subsubsection{Metals}

ANOVA tests showed that concentrations of aluminum were significantly higher in the TFS $(55400 \pm 3200 \mathrm{mg} / \mathrm{kg})$ than the soil $(24100 \pm 1100 \mathrm{mg} / \mathrm{kg})$, which is consistent with previous results that found increased aluminum content in TFS from the Al-containing motor fuel exhaust. ANOVA tests on the other metals also demonstrated that TFS contained significantly higher chromium and nickel than the test site background soil, while concentrations of arsenic, barium, beryllium, iron, lead, selenium, thallium, vanadium, and zinc were significantly lower in TFS compared to soil. There were no differences in the levels of antimony, cadmium, cobalt, copper, and manganese (data not shown). The reasons for the statistical differences are unknown but the differences are not environmentally relevant.

\subsubsection{TFS characterization from other static tests}

Samples of TFS were collected from three other static tests and characterized as described for the FSM-17 TFS. Although the aluminum and chloride concentrations vary, all 
TFS contains significantly more chloride and aluminum than soil collected at the test site (Table $3)$.

Table 2

Summary of anion analysis of TFS and soil

\begin{tabular}{lccc}
\hline Sample & $\begin{array}{c}\text { Chloride } \\
(\mathrm{mg} / \mathrm{kg})\end{array}$ & $\begin{array}{c}\text { Sulfate } \\
(\mathrm{mg} / \mathrm{kg})\end{array}$ & $\begin{array}{c}\text { Nitrate } \\
(\mathrm{mg} / \mathrm{kg})\end{array}$ \\
\hline TFS Site-1 & 34080 & 103 & 3.7 \\
TFS Site-2 & 23260 & 108 & 3.4 \\
TFS Site-3 & 33400 & 93 & 2.1 \\
TFS Average \pm SD & $30200 \pm 6060$ & $101 \pm 8$ & $3.1 \pm 0.9$ \\
Test site background soil & $65 \pm 17$ & $49 \pm 3$ & $10.8 \pm 4.3$
\end{tabular}

Table 3

TFS Characterization from four tests

Static Test (date)

FSM-17 (February 2010)

DM-1 (September 2009)

DM-2 (August 2010)

DM-3 (September 2011)

Test site background soil
Chloride

$(\mathrm{mg} / \mathrm{kg})$

$$
\begin{gathered}
30200 \pm 6060 \\
56100 \pm 1100 \\
69100 \pm 21700 \\
25200 \pm 640 \\
65 \pm 17
\end{gathered}
$$

Aluminum

$(\mathrm{mg} / \mathrm{kg})$

$$
\begin{gathered}
55400 \pm 3200 \\
65100 \pm 720 \\
70400 \pm 4860 \\
31500 \pm 3100 \\
24100 \pm 1100
\end{gathered}
$$

\subsection{Site characterization}

Temperature and humidity were monitored throughout the year at each of the three sites

(Figure 3). Although temperature and relative humidity varied through the year, there were no significant differences between the three sites on a given sampling date. Time of wetness (TOW), defined as the time that relative humidity is in excess of $80 \%$ and the temperature is above 0 degrees Celsius, is considered a key parameter impacting corrosion processes. Based on 
the site-specific temperature and humidity data collected using the HOBO temperature/humidity dataloggers, TOW was zero during duration of study.

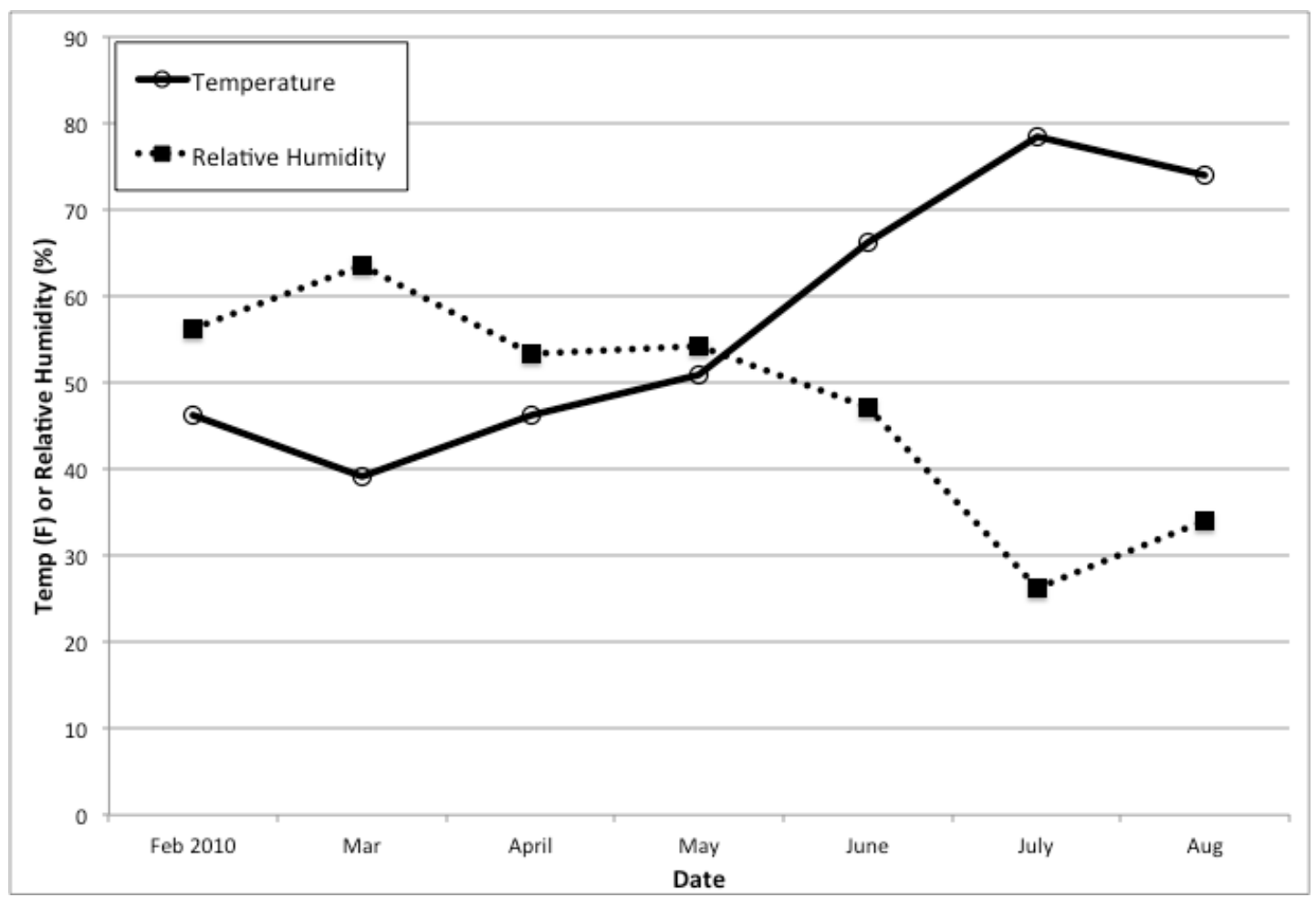

Fig. 3. Average temperature and relative humidity for all sites.

\subsection{Corrosion results}

As expected, all coupons corroded during their six-month exposure to ambient environmental conditions. However, as illustrated in Figure 4, within the first week coupons on the exposed panels showed visibly more corrosion compared to the non-exposed coupons. For the duration of the study, there was no significant site effect on the corrosion rates for the nonexposed coupons (all three non-exposed sites had the same rate at a given time), and these nonexposed coupons had significantly lower corrosion rates compared to the coupons exposed to TFS (Table 4). Corrosion rates at all sites decreased with time, likely due to the formation of a protective rust layer on the surface (Knotkova-Cermakova et al 1982), but the exposed coupons always had a greater rate than the non-exposed coupons. For each of the five sampling events, the corrosion rates of TFS-exposed coupons at Sites 2 and 3 were the same, and both had a significantly higher corrosion rate than Site 1. This is consistent with the TFS deposition pattern 
observed during the test, with Sites 2 and 3 receiving more TFS and calculated amount of chloride (deposition rate multiplied by TFS chloride concentration) than Site 1 (Tables 1 and 2). This could also be due to the panels at Site 1 being knocked over during the first week, which may have dislodged some of the deposited TFS and thus decreased the observed corrosion. Overall, the corrosion rates observed in this study were lower than the rate of 42 mpy seen at the space shuttle launch site in Kennedy Space Center in FL, but comparable to several marine and industrial sites (0.05 - 21 mpy) (Coburn, 1978).

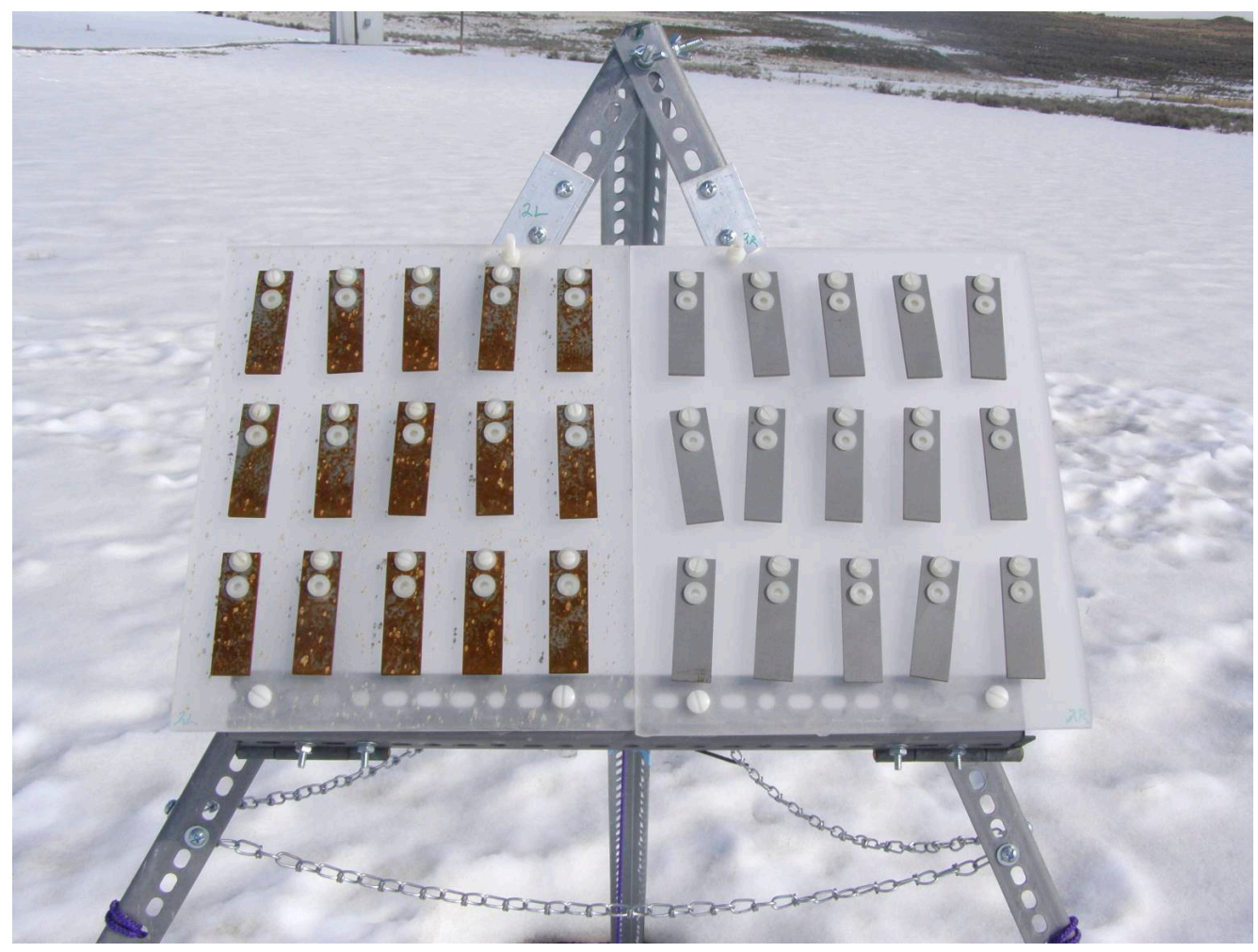

Fig. 4. Example photograph of exposed (left panel) and non-exposed (right panel) mild steel coupons at Site 2, one week after February 25, 2010 static test. 
Table 4

Corrosion rates ( \pm values indicate standard deviation of triplicate samples)

\begin{tabular}{|c|c|c|c|c|c|c|}
\hline & \multicolumn{2}{|c|}{ Site 1 (mpy) } & \multicolumn{2}{|c|}{ Site 2 (mpy) } & \multicolumn{2}{|c|}{ Site 3 (mpy) } \\
\hline Date & Exposed & $\begin{array}{c}\text { Not } \\
\text { Exposed }\end{array}$ & Exposed & $\begin{array}{c}\text { Not } \\
\text { Exposed }\end{array}$ & Exposed & $\begin{array}{c}\text { Not } \\
\text { Exposed }\end{array}$ \\
\hline March 4, 2010 & $3.33 \pm 0.53$ & $1.60 \pm 0.47$ & $5.00 \pm 0.37$ & $1.78 \pm 0.03$ & $4.75 \pm 0.86$ & $1.69 \pm 0.26$ \\
\hline April 2, 2010 & $0.31 \pm 0.01$ & $0.09 \pm 0.00$ & $0.44 \pm 0.07$ & $0.13 \pm 0.01$ & $0.61 \pm 0.02$ & $0.14 \pm 0.01$ \\
\hline June 17, 2010 & $0.19 \pm 0.02$ & $0.17 \pm 0.02$ & $0.32 \pm 0.03$ & $0.23 \pm 0.03$ & $0.34 \pm 0.01$ & $0.13 \pm 0.00$ \\
\hline July 20, 2010 & $0.13 \pm 0.00$ & $.08 \pm 0.01$ & $0.24 \pm 0.01$ & $0.12 \pm 0.00$ & $0.22 \pm 0.01$ & $0.10 \pm 0.00$ \\
\hline Aug. 17, 2010 & $0.10 \pm 0.00$ & $0.05 \pm 0.00$ & $0.14 \pm 0.01$ & $0.08 \pm 0.00$ & $0.14 \pm 0.06$ & $0.05 \pm 0.01$ \\
\hline
\end{tabular}

It should be noted that to address local residents' concerns regarding other materials commonly subjected to TFS deposition, a follow-up test was conducted following the August 31 2010 DM-2 test. On September 7, 2010, a metal stand was placed at the ATK facility with four coupon types: mild steel (as described above), painted automotive steel (Chevrolet full-size pickup hood, model year 2005), painted galvanized steel (Fabral Shelterguard 29-gauge), and vinyl (Rain Master vinyl downspout). TFS that was deposited on a local barn roof was collected and made into a slurry with deionized water (3:7 TFS:water), then sprayed onto one set of coupons using a Wagner PowerTex Handheld Texture Sprayer. The ratio of TFS:water was selected by trying different alternatives until one visually approximated the consistency of the deposition observed during the February 25, 2010 test. A second (non-exposed) set of coupons was placed on the rack for comparison. Automotive steel, painted galvanized steel, and vinyl coupons left in the field for six months showed no visual signs corrosion due to the application of TFS. ANOVA analysis also showed no statistically significant weight loss in these coupons.

\subsection{Conclusion}

The deposition resulting from the static testing of large horizontally restrained rocket motors has not been previously collected and chemically characterized. Depositional material collected during a February 2010 static test was found to have elevated levels of chloride and showed corrosive properties based on weight loss measurement from field deployed mild steel test coupons. The elevated chloride levels were not surprising given the interaction of the plume entrained soil with the rocket fuel combustion products. Ongoing studies are focused on the 
potential impact of the deposition on crop plants grown on the surrounding farms.

\section{Acknowledgements}

This work was funded by ATK Launch Systems and the Utah Water Research Laboratory. The authors would like to thank the following people for their assistance: Julie Chard, Randy Martin, Heather Klein, Kimberly Barton, Danny Ryan, Renn Lambert, and Justin Heavilin.

\section{References}

Coburn S. Atmospheric corrosion. In: Metals Handbook, Vol. 1: Properties and Selection, Carbon Steels. American Society for Metals, Metals Park, OH, 9 ${ }^{\text {th }}, 1978 ; 1: 708$.

Cofer, W.R., Winstead, E.L., Purgold, G.C., and Edahl, R.A. Solid propellant exhausted aluminum oxide and hydrogen chloride: Environmental Considerations AIAA 31st Aerospace Sciences Meeting and Exhibit, Reno, NV, 1993.

Dreschel TW, Hall CR. Quantification of hydrochloric acid and particulate deposition resulting from space shuttle launches at John F. Kennedy Space Center, Florida, USA. Environmental Management 1990; 14:501-507.

Knotkova-Cermakova D, Vlckova J, and Honzak J. Atmospheric Corrosion of Weathering Steels. In: Dean SW and Rhea EC, Editors. Atmospheric Corrosion of Metals. ASTM International, West Conshohocken, PA, 1982; p. 7-44.

Nowak J, Friend AL. Loblolly pine and slash pine responses to acute aluminum and acid exposures. Tree Physiology 2006; 26:1207-1215.

R Core Team. R: A Language and Environment for Statistical Computing, R Foundation for Statistical Computing, Vienna, Austria, 2012.

US Environmental Protection Agency (US EPA), Method 3050B: Acid Digestion of Sediments, Sludges, and Soils, www.epa.gov/osw/hazard/testmethods/sw846/pdfs/3050b.pdf 1996. US Environmental Protection Agency, Method 6020A: Inductively Coupled Plasma-Mass Spectrometry, www.epa.gov/osw/hazard/testmethods/sw846/pdfs/6020a.pdf. 2007. 
Von Ende CN. Repeated-measures analysis. In: Scheiner SM and Gurevitch J, editors. Design and Analysis of Ecological Experiments. Oxford University Press, New York NY, Second Edition, 2001; p. 143-144.

Winer, B. J., Brown, D. R., \& Michels, K. M. Statistical Principles in Experimental Design, Third ed., McGraw Hill, New York, NY, 1991. 